\title{
Islamic Law and Imperialism: Tracing on The Development of Islamic Law in Indonesia and Malaysia
}

\author{
Ahmad Imam Mawardi \\ (Faculty of Sharia and Law, Islamic State University of Sunan Ampel, \\ Jl. Ahmad Yani No. 117 Jemur Wonosari Surabaya, \\ email: aimawardi1970@gmail.com)
}

\begin{abstract}
Abstrak
Artikel ini bertujuan membuktikan bahwa imperialisme atau kolonialisme memiliki pengaruh besar terhadap perkembangan hukum di negara-negara yang dijajah. Tradisi hukum di negera jajahan dalam banyak bidang mengikuti tradisi hukum negara penjajah. Dalam kasus Indonesia, penjajahan Belanda selama tiga setengah abad menjadi penyebab aktif dan kuatnya warna institusi dan sistem hukum Euro-centric. Karena Belanda sendiri mengadopsi hukum Perancis, maka sistem hukum di Indonesia secara tidak langsung dipengaruhi oleh hukum Perancis, yakni tradisi hukum Romawi. Sementara itu, Malaysia yang dulunya dijajah oleh Inggris dan sampai saat ini menjadi anggota Commonwealth Countries (Negara Persemakmuran) menunjukkan saturasi yang sama dengan hukum Inggris, yakni tradisi hukum Inggris (common law). Perbedaan dari dua tradisi hukum di atas terletak pada fakta bahwa tradisi hukum Romawi memiliki semangat pembaharuan, reformasi, dan kodifikasi hukum yang sangat kuat, sementara tradisi hukum Inggris enggan mengikuti karakter tersebut demi menjaga tradisi yang telah berkembang lama.
\end{abstract}

\section{Kata Kunci:}

Roman Law, Common Law, Indonesia, Malaysia

\begin{abstract}
This article is to prove that imperialism or colonialism has a great impact on the legal development in colonized countries. The legal tradition of colonized countries to a large extent follows the legal tradition of the colonizer. In the case of Indonesia, Dutch colonization for three and a half centuries were active promulgators of Euro-centric institutions and legal systems. As the Dutch had themselves adopted the French legal system, Indonesia's legal

al-Ihkâm Vol.13 No.1 Juni 2018

DOI 10.19105/al-ihkam.v13i1.1583
\end{abstract}


system was, in turn, indirectly influenced by French law, i.e., Roman law tradition. Meanwhile, Malaysia, today commonwealth members and former British colonies, exhibits similar levels of saturation with English law, i.e, common law tradition. The difference between the two legal traditions above lies in the fact that Roman law has a spirit of legal renewal, reform, and codification, while common law resisted these tendencies in the name of tradition.

\section{Keywords:}

Roman law, common law, Indonesia, Malaysia

\section{Introduction}

The arrival of Islam to Indonesia and Malaysia shares a similar historical root since both countries locate in the same geographical landscape. This fact leads to the similarities of the original nature of Islamic law in both countries, i.e., following Shafi'ite mazhab (school of thought) and is accommodative to the local traditions. However, the later development of Islamic law shows different trajectories. Islamic law in Indonesia and Malaysia experienced different destinies by the coming of colonialization; the former was colonized by the Dutch and the latter was colonized by Britain.

Colonialism or imperialism ${ }^{1}$ has a close connection with the cultural development in colonized countries as depicted in Edward W. Said's research on the root of imperialism in the Western culture and its impact on cultural development in the world. In his book Culture and Imperialism, Edward Said attributes the tendency of dominating, ruling and having authority over others to chauvinist attitudes of cultural supremacy in which the mainstream culture of colonizer influences the culture of colonized countries. To him, imperialism is

1 The term "imperialism" has a lot of meaning. Norman Etherington in his book, Theories of Imperialism, War, Conquest and Capitals,' defines it as "despotic methods of government," "empire building," "employing the power of the armed state to secure economic advantages in the world at large.' Norman Etherington, Theories of Imperialism, War, Conquest and Capitals, (Croom Helm, 1984), v; In political science, the word "imperialism" tends to be understood as dominating, restructuring and ruling and having authority. 
considered as "the practice, the theory, and the attitudes of a dominating metropolitan center ruling a distant territory." 2

Although Said's theory is too general to include every aspect of culture (with specific reference to the literary discourse), it can be extended to the realm of law where the indigenous legal systems in colonialized countries were subordinated to colonial ones. Typically, the colonizers viewed their legal system as efficient and dynamic while dismissing that of the colonized as inferior. The study on culture, in this context, will not be a reliable and comprehensive one if the impact of colonialism on the development of Islamic law is ignored. ${ }^{3}$

The influence of colonial law on many former Muslim colonialized countries cannot, therefore, be denied. Legal developments in Egypt, ${ }^{4}$ Saudi Arabia, ${ }^{5}$ and India, ${ }^{6}$ for instance, are the testament to this process. French law and English law exercised the most influence on legal systems within the colonized countries. The

2Edward W. Said, , Culture and Imperialism (New York: Vintage Books, 1993), 9.

${ }^{3}$ Edward W. Said, xiv. Edward Said provides very strong evidence to support his conclusion by reading and analyzing the genre and stylistics of some novels in colonized countries. He says: "The novels and other books I consider here I analyze because first of all I find them estimable and admirable works of art and learning, in which I and many other readers take pleasure and from which we derive profit. Second, the challenge is to connect them not only with that pleasure and profit but also with the imperial process of which they were manifestly and unconcealed a part; rather than condemning or ignoring their participation in what was an unquestioned reality in their societies, I suggest that what we learn about this hitherto ignored aspect actually and truly enhances our reading and understanding of them".

${ }^{4}$ Ron Shaham on legal reform Egyptian Shari'a Courts, Ron Shaham, "Custom, Islamic Law, and Stawary Legislation: Marriage Registration and Minimum Age at Marriage in the Egyptian Shari'a Courts," Islamic Law and Society 2, no. 3 June (1995).

${ }^{5}$ Maren Hansen, "The Influence of French Law on the Legal Development of Saudi Arabia," Arab Law Quarterly 2, no. 3 August (1987).

${ }^{6}$ The British influence on Legal systems in India is well documented by Kidder. See Robert L. Kidder, "Western Law in India," in Social System and Legal Process, ed. Harry M. Johnson (et.al) (Sun Fransisco, Washington and London: Jossey-Bass Publishers, 1978), 155-80. 
parity between Islamic legal institutions and French and English legal codes is a striking and persistent feature of the postcolonial world such as Indonesia and Malaysia.

Dutch colonization for three and a half centuries were active promulgators of Euro-centric institutions and legal systems. As the Dutch had themselves adopted the French legal system, Indonesia's legal system was, in turn, indirectly influenced by French law. Malaysia, today commonwealth members and former British colonies, exhibits similar levels of saturation with English law. Since Islamic law with its attendant institutions had been applied before the European incursions, one must question the degree to which colonial law left its imprint on the former. In an attempt to answer this question, we must investigate the original position of Islamic law in society and its relation to the adat law before the advent of colonialism.

\section{Adat Law and Islamic Law in Early Indonesian and Malay Societies}

It is a general understanding that Islam came to Nusantara, the Malay world, before the colonial European era. Islamic law had debuted in Indonesia with Islam's early introduction to the archipelago. ${ }^{7}$ Nevertheless, scholars disagree on the exact date of Islam's arrival to the archipelago. S. Q. Fatimi ${ }^{8}$ and Syed Naquib Alatas, ${ }^{9}$ for examples, say that the first wave of conversion to Islam occurred in the eighth century, ${ }^{10}$ many others such as Schrieke,11

7 Muhammad Daud Ali, "Kedudukan Hukum Islam dalam Sistem Hukum Indonesia," in Tradisi dan Kebangkitan Islam di Asia Tenggara, ed. Taufik Abdullah and Sharon Siddique (et.al) (Jakarta: LP3ES, 1989), 208. See also Panitia Penyusun Biografi, Prof. KH. Ibrahim Hosen Dan Pembaharuan Hukum Islam Di Indonesia (Jakarta: Putra Harapan, 1990), 101.

${ }^{8}$ His opinion about the coming of Islam to Nusantara is presented in his Islam Comes to Malaysia. In this book he attempts to answer three questions; where, when, and how did Islam come to Malaysia, which automatically addresses the coming of Islam to Indonesia. See: S. Q. Fatimi, Islam Comes to Malaysia (Singapore: Malaysia Sociological Research Institute, 1963).

9 Syed Naquib Alatas, Preliminary Statement on General Theory of Islamization of the Malay-Indonesian Archipelago (Kuala Lumpur: Dewan Bahasa dan Pustaka, 1969).

${ }^{10}$ Many other scholars support this opinion such as : N. A. Bollach, The Advance of Islam in Indonesia (Islamabad: NIHCR, 1980); Syed Farid Alatas in 
Barrison, ${ }^{12}$ and Hall ${ }^{13}$ assert that it took place as late as thirteenth century.

In pre-Islamic history, the main source of law was adat law or the rules, customs, usage and practices developed, applied, rooted and based on social consensus. ${ }^{14}$ The coming of Islam to Nusantara, the Malay peninsula and the Indonesian archipelago, with its new legal norms did, of course, bring about a new discourse on the law. Large scale conversion to Islam by the people of Nusantara, 15 in turn

his article "Notes on Various Theories Regarding the Islamization of the Malay Archipelago" in Muslim World 75 No.3-4 (July-October, 1985), 162-175 holds a similar conclusion. Muhammad Daud Ali in his "Kedudukan Hukum" in Tradisi dan Kebangkitan, 208, arrives at a similar conclusion of the seminar on the coming of Islam to Indonesia that was conducted in Medan in 1963.

11 B. Schrieke, Indonesian Sociological Studies (Den Haag: W. van Hoven, 1955), 7-37.

12 Brian Barrison, Southeast Asia: A Short History (London: Mcmillan \& Co, 1957), 50-60.

13 D. G. E. Hall, A History of Southeast Asia (London: Mcmillan \& Co, 1964), 190-204.

14 In anthropological and legal studies concerning Malay societies, adat law is always depicted as an order of beliefs and customs or usages that are at odds with Islamic values. See E. N. Taylor, "Aspects of Customary Inheritance in Negeri Sembilan," in Reading in Malay Adat Laws, ed. M. B. Hooker (et.al) (Singapore: University of Singapore Press, n.d.), 163. The term "adat law" or "Adat Recht" in the case of Indonesia, according to Jan Prins, came into use about 1900. See Jan Prins, "Adat Law and Muslim Religious Law in Modern Indonesia," The World of Islam 1 (1951): 283-284.

${ }^{15}$ Lapidus mentions three factors that eased the Nusantara people into an acceptance of Islam: the role of Muslim merchants who actively involved in social life with local citizens by marrying the local women and sharing the diplomatic knowledge and skills on trade with local rulers, the role of sufi in communicating Islamic teachings, and the value of Islam itself, I. M. Lapidus, A History of Islamic Societies (Cambridge: Cambridge University Press, 1988), 469. See also the quotation of Lapidus' notion by Gavin W. Jones, Marriage and Divorce in Islamic South-East Asia (Kuala Lumpur: Oxford, Singapore, and New York: Oxford University Press, 1994), 2. Regarding the motivation behind the acceptance of Islam by Nusantara society, Winstedt concludes that it was motivated by the political interests of local rulers who accrued the great economic benefit and strong diplomatic relations with the foreign traders 
influenced and modified the practice of adat law. J.N.D. Anderson's statement on the relationship between Islamic law and adat law in Indonesia and Malaysia is perhaps the best example of those who would neglect this phenomenon. Anderson states that "...another futile source of conflict is between customary law and divine law, as exemplified, for instance, in those Muslim communities - whether in Africa, Malaya (Malaysia) or Indonesia."16

To view the relationship between Islamic law and adat law as purely conflict-ridden is to assume that Islam was brought into forceful confrontation with local customs. Given the fact that Islam spread peacefully in the archipelago, the influence of Islamic law on adat law can be interpreted as an acculturative process necessitated by a high level of cultural interaction.

Adat laws in Indonesia were never uniform but were instead tailored, regulated and applied based on regional custom. The arrival of Islam did not signal the end of adat law. In Minangkabau, for instance, adat law remained strong until the nineteenth century. ${ }^{17}$ Furthermore, Islamic law and adat functioned as twin legal pillars, which came to exert a mutual influence. ${ }^{18}$ Islam's rapid spread through the efforts of traders, ulama, and Sufis to the Nusantara region facilitated the introduction of the shari'a as a legal canon to many of the kingdoms of Nusantara. ${ }^{19}$ Demak, Jepara, Malacca, and Mataram were among the kingdoms to apply Islamic law.

through the conversion into Islam, See Winstedt, The Malays: A Cultural History (Singapore: Kelly and Walsh, 1947), 27.

16 J. N. D. Anderson, "Reflection on Law-Natural, Divene and Positive," in 940'th Ordinary General Meeting of the Victoria Institutes (Westminster, 1956), $1-23$.

${ }^{17}$ Robert van Niel, "The Course of Indonesian History," in Indonesia, ed. Ruth T. McVey (et.al) (New Haven: SAS Yale University, n.d.), 277.

18 This may be caused by the flexibility of Islamic legal theory which views 'âdah (custom) or 'urf (usage) as supplementary sources of Islamic law as affirmed by the formula "al-'âdah muhakkamah". Through this flexibility, the peoples who converted to Islam may continue their customs, traditions, or adat as far as there are not contradictory to the al-Qur'an and Prophetic Traditions (hadith).

19 The spread and early development of Islamic law in Indonesia can be read in Robert van Niel, "The Course of Indonesian History," 276-78. 
In Malaysia, there are two main branches of adat law that are still practiced up to now, namely adat Pepateh (Pepateh legal system) and adat Temenggung (Temenggung legal system). ${ }^{20}$ The Pepateh legal system is considered the first Malay adat law and follows exogamy derived from a matrilineal structure that originates from the tribal laws applied in Minangkabau (transformed into the Malay Peninsula by the first Minangkabau immigrants in the $16^{\prime}$ th century). The Temenggung legal system, on the other hand, tends to follow a bilateral system of social organization with specific emphasis on endogamy and patrilineal system which originates from Southern Sumatera with its autocratic and patriarchal Hindu institutions. Before Islam, these two adat laws were characterized by their oral narrative form.

Once Islam was well established, undeniable change overtook the procedure and substance of adat law as a result of the influential tradition. Isma'il bin Mat has critiqued the majority of legal and social scientists to describe Islamic jurisprudential theory as marginal to the Malay jurists who compiled the copies of the Malay Digests. ${ }^{21}$ Moreover, Mat argues for the existence of Islamic influence on the Malay legal Digests, suggesting that the "Islamization" of the two major adat laws, Papateh and Temenggung, had long been underway. ${ }^{22}$

${ }^{20}$ Isma'il bin Mat, "Adat and Islam in Malaysia: A Study in Legal Conflict and Resolution" (Temple University, 1985), 35-36.

${ }^{21}$ In the case of Islam in Malay and, to some extent, Indonesia, some legal scholars and social scientists tend to regard the Islamic influence as if there were a total structural deconstruction and Islamic reconstruction. Consequently, they tend to ignore small and gradual changes as a result and process of Islamic influence itself. Finally, they fell into faulty generalization by saying that the impact or influence of Islam in the Region was not significant until the twentieth century. Among the faulty generalizations, see Raymond L. M. Lee, "The Ethnic Implication of Contemporary Religious Movements and Organizations in Malaysia," Contemporary Southeast Asia 8, no. 1 (1986): 70.

${ }^{22}$ For detailed information and analysis on the Islamic contents of the Malay legal digests, see Ismail bin Mat, Adat and Islam in Malaysia, p. 38-40; Besides, Anthony J. S. Reid says that although it was not rigorous, the implementation of Islamic law was there in 1960. See Anthony J. S. Reid, "Southeast Asia in the Age of Commerce 1450-1680," in The Lands Below the Winds, 1st ed. (New Haven: Yale University Press, 1988), 157-58. 
The speed with which Islamic legal influences spread varied from one state to the next depending on the strength of Islamic da'wah and the adaptability of local adat to Islam.

The influence of Islamic jurisprudence on Malay adat law is the most felt in the areas of material or substantive law, as is apparent from the Malay legal digests. ${ }^{23}$ Procedural and institutional areas of the legal system do not seem to have changed, however. This event, to some extent, indicated the harmonious relationship between adat and Islam and showed the great demand of Muslims to apply Islamic law. It was in 1880 that the British approved the enforcement of the Mohamedan Marriage Ordinance, which regulated Muslim marriage and divorce.

The colonial era, with its new western legal discourse, thus influenced the development of Islamic law in the modern states of Malay Archipelago. To follow the path of western legal influences, a preliminary discussion on British (Common) law and Roman law is needed.

\section{Common-Law and Roman Law}

The difference between Roman law and common law is, among other things, a legal consequence of divergent legal concepts. Legal scholars and socio-anthropologists would probably eschew any set definition of law. While acknowledging this difficulty, definitions of law may still be divided into two categories: legal philosophers such as John Austin and Wendel Holmes, for instance, emphasize a definition of law predicated on the existence of a sovereign and courts; while anthropologists such as Hartland and Adamson Hoebel emphasize the traditional and indigenous roles of the law. ${ }^{24}$ An innovative approach, adopted by sociologists such as Feeley, Quinney and Balbus defines law from a radical perspective which views it to the social order. This

23 Those digests are Malacca Digests or Undang-Undang Malaka, digests of Kedah Laws, digests of Selangor, and a Johor digests.

24 Isma'il bin Mat, "Adat and Islam in Malaysia: A Study in Legal Conflict and Resolution," 32-33. 
is a departure from the traditional emphasis on the character of law itself. ${ }^{25}$

Common law and Roman law are two schools that continue to affect the modern legal realm. Most nations today follow one of these two major legal traditions. Common law, also known as English law, was pioneered by the British government, while Roman law was championed by the French, also known as French law. Both are now considered the major legal schools to which most countries subscribe. Common law exerts great influence in many of the former Commonwealth countries and several African countries, while Roman/Germanic law is very influential throughout Europe, and many of France's former colonies in Latin America, Africa, and the Middle East.

In their early development, both legal schools diverged on the question of legal unification. Roman law has a spirit of legal renewal, reform, and codification, while common law resisted these tendencies in the name of tradition. ${ }^{26}$ Common law saw the promotion of codification as to break tradition, while the substantive contentment of the law was regarded as a product of a long tradition unchanged by revolution. ${ }^{27}$ However, in its socio-historical sojourn, common law could not remain a loaf to sweeping legal developments in other parts of the world. The change here, however, was marked by a process of evolution, not revolution. In the modern world, common law has accommodated the notion of reform and codification, but has not, unlike Roman law, seen it as a practical imperative. In reality, therefore both laws have demonstrated adaptability to new circumstances and

25 See Quinney and Balbus Feeley, The Sociology of Law: A Conflict Perspective, ed. Charles E. Reasons and Robert M. Rich (et.al.) (Toronto: Butterworths, 1978). This book includes articles of Malcom M. Feeley, "The Concept of Laws in Social Science: A Critique and notes on an Expanded View", Richard Quinney, "The Ideology of Law: Notes for a Radical Alternative to Legal Oppression", and Issac D. Balbus, "Commodity Form and Legal Form: An Eassay on the Relative Autonomy of Law."

${ }^{26}$ Rene David and John E.C. Brierly, Major Legal System in the World Today: An Introduction to the Comparative Study of Law (London: Stevens \& Son, 1978), 286.

${ }^{27}$ Rene David and John E.C. Brierly, 286-87. 
social needs. For common law, this phenomenon is most observable in the modern period, from 1832 up to the present time. ${ }^{28}$

Friedman distinguishes between English law (or AngloAmerican law) and Roman law based on the social orders surrounding the legal systems. Common law, he states, was based on a gradual development in the tradition, while Roman law was based on codified law. Consequently, legal precedents were considered a source of law for the former, while Roman law regarded it as a legal explanation. The courts in the common system play a central role, therefore. ${ }^{29}$

In short, it may be said that what makes common law different from Roman law is the nature of its legal substance, structure and procedure. The strong commitment to custom, traditions and juridical precedent as sources of the new legislation have popularized common law as case-made law or judge-made law. Roman law which regards codification as a source of law is known as statute-made law.

\section{Method}

In this analysis, the socio-political methodology is employed with particular attention to historical narrative. How the interplay of political interests from both colonial and local governments shaped Islamic legal developments will also be addressed.

The basic theory behind imperialism is closely related to mercantilist policies aimed at the promotion of economic, commercial, and trade interests of the colonizers. On the practical level, these goals were to be pursued in a new culture, tradition, and political system. As the involvement of European imperialism intensified from simple to more complex interaction in the new colony, local administrative and legal traditions were increasingly manipulated to the advantage of the

${ }^{28}$ Rene David and John E. C. Brierly divide the history of English Law into four main periods: 1] before the Norman Conquest in 1066; 2) From 1066 to the accession of the Tudors in 1485 . This period was regarded as the age of formation of Common Law; 3] from 1485 to 1832 in which the idea of" rule of equity" was developed alongside the common law; 4) 1832 up to now in which Common law has faced unprecedented developments in legislation and has to adapt itself to the society directly by the way of governmental and authoritative interference. See: Rene David and John E.C. Brierly, 287.

${ }^{29}$ W. Friedman, Teori \& Filsafat Hukum, ed. Muhammad Arifin (Jakarta: Rajawali Press, 1990), 162-65. 
colonizer. ${ }^{30}$ To remove all barriers to the success of this stated objective, the legal system was configured to reshape the social order, a phenomenon which Jenkins refers to in which law was regarded as an instrument of change. ${ }^{31}$

Moreover, believing that the legal principle of their laws was superior, the imperialists dismissed the indigenous legal system as backward, unfair, and disorganized. The British imperialists in India, for example, with the pride common law, labeled India as "chaotic, lacking law and the victim of capricious and unscrupulous rajas." 32 In Indonesia, the Dutch with their affinity for Roman law, viewed Indonesian law, including Islamic law, neither of which was codified, as an instrument of legal uncertainty. The changes brought to the law in other Malay countries, such as Malaysia and Singapore followed the same pattern.

Although there was a tendency of changing the law, British imperialism with its commitment to a common-law ideal consistently discourages intervention in legal custom and seeks to preserve it. ${ }^{33} \mathrm{~A}$ later development, nonetheless, brought change to local customs and traditional system in Malaysia whenever it proved expedient for the imperialist. In Indonesia, Roman law forced a change to the system of law by introducing new legal administrative procedures and sources. In short, Galanter concludes, that "In modern system, there is a strong and persistent tendency toward the replacement of local and popular law by official lawyers' law." 34

30 Robert L. Kidder, “Western Law in India," 156-57.

${ }^{31}$ Iredell Jenkins, Social Order and The Limit of Law (Princeton: Princeton University Press, 1980), 214. In this page, Jenkins explains that throughout the whole panorama of legal history, there have been three phases of law that can be identified: conservative, liberalizing, and constructive. In the first phase, the law is expected to protect and reinforce an established order that is threatened by disputes. In the second phase, liberalizing phase, the law is considered and used as an instrument of change to shape or reshape certain social order. In the last phase, the law assumes a positive and creative role.

32 Robert L. Kidder, "Western Law in India," 157. See also page 159 in which Kidder lists the feature of colonial law.

33 Robert L. Kidder, 162.

34 M. Galanter, "The Modernization of Law," in Modernization, ed. M. Weiner (et.al.) (New York: Basic Books, 1966), 161. 
By observing local social factors in conjunction with the political interests of the colonialists, the changes and developments of Islamic law in the colonized countries such as Indonesia and Malaysia will be better understood.

\section{Historical Explanation of the Countries as Colonized Countries}

\section{Indonesia}

Islamic law and procedure in Indonesia before $1835^{35}$ were under the full authoritative control of the penghulu (Islamic chieftain or headman) and the chief administrator of mosques and only followed the Shafi'ite madhhab in solving problems ${ }^{36}$ without any significant intervention from the Dutch colonialists. A later development, however, the political interests of the Dutch colonial regime dictated the need for a Western legal model to be introduced to Indonesia. These interests had driven the Dutch to subdue the existing Islamic legal system, as well as the other legal systems, by minimizing their roles and limiting their jurisdiction. The manifestation of Dutch political interest, interestingly, worked behind the rationality of codification of Roman law.

In Dutch eyes, Islamic courts were not well established or organized when measured against their law, a judgment which was reinforced by the legal sources to which the Islamic court referred were not codified. As such, the Dutch endeavored to change Islamic institutions without losing sight of their original goal to minimize the influence of Islamic law. In general, the Dutch interventionist model can be divided into two eras and categories. The first era commenced with the establishment of the VOC (Vereenigde Oost Indische Compagnie/Dutch East India Company) in 1602, when the Dutch began actively intervening in the practice of Islamic law, until 1875. At this

35 The Staatblad 1935 no. 58, noted the resolution dated 7 December 1935, interpreted the stbl. 1820 no. 20 by stating that if there is any dispute among Javanese people stemming from the decisions made by religious leaders (ulama) on the matters of marriage, inheritance and alike, the matters should be given (offered) to common (public) courts.

${ }^{36}$ Danies S. Lev, Islamic Court in Indonesia: A Study in the Political Bases of Legal Institution (London: University of California Press, 1972), 10-40. Mark Cammack, "Islamic Law in Indonesia's New Order," The British Institute of International and Comparative Law 38, no. January (1989): 55. 
juncture, the government was still lenient and respectful of the religious court family law among Muslims. ${ }^{37}$ In 1923, the religious court in Palembang was founded based on resolution no. 12 from the general governor. The move to codify public law, including Islamic law, began in earnest in 1838 based on the concordant legal principle in the Netherlands. This soft interventionist policy may have been influenced by Dutch legal scholars who, at that time, felt that unless Islamic law remained the main legal source for Muslims, chaos and clash would surely result. ${ }^{38}$

The year 1875 witnessed the beginning of a new era lasting until 1942. In this period, Dutch scholars began to change their views. Federspiel notes that this change was marked by a new appraisal in which Islamic law was no longer seen to be deeply rooted in the community. Instead, it was adat law that was henceforth accepted as the pervasive practice of society. ${ }^{39}$ In 1882 Dutch established a model of religious courts based on Staatbad no. 152 articles 1, which stated that religious courts were to be established whenever there was a civil court and that the geographical jurisdiction of religious courts should be in compliant with that of the civil court. ${ }^{40}$ Through this staadblad, another religious Court in Java and Madura was established.

Later on, in 1937, the kadi system was established in South and East Kalimantan, namely Kerapatan Qadi and Kerapatan Qadi Besar, based on Staatblad 1937 no. 638 and 639. From 1908 until 1942, Dutch intervention faced a new barrier in the form of revolt stemming from

37 Regeeringsreglement (RR) 1854 article 78, stating the unauthoritativeness of Religious Court to process Criminal Law, emphasized the authority of Religious Court to solve problems on family law among indigenous people, Chinese, Indians, Arabs, and Malays who were Muslim

38 Regarding Dutch scholarship and its role in the development of Islamic Law in Indonesia can be read in Howard M. Federspiel, "The Importance of Islamic Law in Twentieth-Century Indonesia" (Ohio, 1995). Mr. Scholten Van Oud Haarlem and Van Den Berg, with its theory receptio in Complexu, are among the popular names supporting the idea of continuity of using Islamic Law in solving Muslim dispute.

${ }^{39}$ Howard M. Federspiel, 1.

${ }^{40}$ Cammack, "Islamic Law in Indonesia's New Order," 54. 
vigorous nationalists' movements. ${ }^{41}$ Muslim's desire to entrench Islamic legal practice heralded a new phase in Islamic legal developments.

The Dutch left Indonesia in 1942, bequeathing the nation of codification and the bifurcation of religious courts from public courts to the modern nation-state of the Malay Archipelago. Then, Japanese occupied Indonesia until 16 August 1945 but no significant change took place in this period. Since independence, 17 August 1945 up to the present, the development of Islamic law in Indonesia, in terms of its acceptance by the Indonesian government, also fell into two categories identified by Ismail Sunny: the acceptance of Islamic law as a persuasive source of law and the acceptance of Islamic law as authoritative law. ${ }^{42}$ Islamic law as a persuasive source of law was recognized for 14 years, from 1945 until the emergence of presidential degree in 1959 as shown in the adoption of "the obligation to Muslim to apply Islamic Shari'a" 43 which was included in the Constitution. Since the emergence of the Presidential Degree, in which the seven words of the Jakarta Charter above were firstly included, the Islamic law becomes an authoritative source.

The Dutch law codification gained wide currency in Indonesia where legal certainty became the imperative of law. The limitation imposed on jurists in 1956 to use 13 figh texts only, ${ }^{44}$ was a preliminary step toward the unification and codification of Islamic law. Government Regulation no. 14/1970, the law of marriage no. 1/1974 and the Religious Bill no.7/1989 are among those efforts towards codification and the establishment of religious court as equal partners to the three other courts in Indonesia.

41 Howard M. Federspiel, "The Importance of Islamic Law in Twentieth-Century Indonesia," 6.

42 Isma'il Sunny, "Kedudukan Hukum Islam dalam Sistem Ketatanegaraan Indonesia," in Dimensi Hukum Islam Dalam Sistem Hukum Nasional, ed. Amrullah Ahmad (et. al.) (Jakarta: Gema Insani Press, 1996), 133.

43 This quotion is a translation of Indonesian words: "dengan kewajiban menjalankan syariat Islam bagi pemeluk-pemeluknya." These words are in the Jakarta Charter which is famous as "seven words" that become evidence of Muslims powerful participation in the political arena that time.

44 This limitation of selected figh books was based on the letter of Religious Judiciary Beaureu no. B/1/735 dated 18 February 1958. 


\section{Malaysia}

Like Indonesia, Malaysia had applied Islamic teachings, including Islamic law, together with adat law before the colonial era. However, in terms of the colonial experience, Malaysia and Indonesia did not share one destiny. Generally speaking, British involvement in Malaysia can be divided into three stages. The first stage from $1786^{45}$ to 1867, commenced when the East India Company established outposts in Penang, Singapore and Malacca. The second stage, from 1874 to 1895, saw the signing of treaties by the British with the State Rulers of Perak, Selangor, Negeri Sembilan and Pahang (called also the Federated States of Malaysia). ${ }^{46}$ The last stage, between 1909 and 1923, unfolded when the not-federated States of Kedah, Perlis, Kelantan, Terengganu and Johor came under British protection through separate treaties. British attitudes toward Islam and Muslims were not marked by caution and antagonism compared to Dutch attitudes in Indonesia.

The British viewed Islamic teachings in Malaysia as an integral part of the local culture they wished to preserve. However, as it was the nature of imperialism to facilitate the realization of certain political and economic ends, the British gradually persuaded the rulers and people to accept English law. Since Malaysia was comprised of many states to which, in turn, the British came many times at different years and duration to different parts of Malaysia, ${ }^{47}$ their intervention and the level of their influence was not uniform. Initially, the British influence

45 The travels of British people in Malaysian water in the sixteenth century are not regarded as the real advent of English settlement in Malaysia. Rather, it is the year 1786 when the British people actively interacted with Malaysians.

46 This treaty was in an exchange for British recognition of their claims to be rulers of the states. Each state agreed to accept British residents and follow their advise in all matters other than Mohammedan religion. See Rais Yatim, Freedom under Executive Power in Malaysia (Kuala Lumpur: Endowment Sdn. Bhd, 1995), 37.

${ }_{47}$ British colonialists controlled Malacca in 1824, Perak in 1873, Selangor in 1874, Pahang in 1888, and Negeri Sembilan in 1889. 
changed and reorganized Islamic legal systems only gradually especially in the matters of procedural law, not in material law. ${ }^{48}$

The radical change in legislative and procedural law in Malaysia occurred with the promulgation of many charters of justice. The Charter of Justice granted in 1807, for instance, forced Penang to apply English law, the Charter of Justice of 1826 forced the replacement of Islamic law, operative in the region since 1414, with the English law. ${ }^{4}$

Charter of justice became a legal phenomenon in Malaysia through which the British imposed the use of English law in Malaysia. Another means by which the British proposed to promote their law was by controlling the legal process in Islamic courts. The Jurisdiction of the Kadi and the independence of the Islamic courts were compromised leaving the administration of Muslim law to the control of English advisors Federated Malay states, including Perak, Selangor, Pahang, and Negeri Sembilan. ${ }^{50}$

Serawak and Sabah have another history. English law was very late debuted in these areas; 1928 in Serawak and 1938 in Sabah. Later, the promulgation of the Administration of Muslim Law Enactment in 1977 in Sabah, and the Majlis Ugama Islam Ordinance in 1978 in Serawak, amalgamated the situation and brought these two states in line with other states of the Malay Peninsula. ${ }^{51}$

\section{Comparative Analysis}

The above description of colonial experiences in Indonesia and Malaysia relays the important role played by the European powers in shaping new models or systems of law throughout the countries of the

${ }^{48}$ See Sharifah Zal Syed Hassan, "From Saints to Bureaucrats: A Study of the Development of Islam in The State of Kedah Malaysia" (Cornell University, 1985), 127-128.

49 Isma'il bin Mat, "Adat and Islam in Malaysia: A Study in Legal Conflict and Resolution," 49-50.

50 Isma'il bin Mat, 55. See also Ahmad Ibrahim, "The Position of Islam in the Constitution of Malaysia," in The Constitution of Malaysia; Its Development: 1957-1977, ed. Muhammad Sufyan (et.al.) (Kuala Lumpur: Oxford University Press, 1978), 57.

51 Isma'il bin Mat, "Adat and Islam in Malaysia: A Study in Legal Conflict and Resolution," 60. 
region. The main question is, then, to what extent are Islamic legal developments after independence still influenced by the European legal system, French/Dutch law on Indonesian Islamic law and British/English law on Islamic law in Malaysia.

In the case of Indonesia, legal developments in the early postindependence 1945 were still influenced by general Dutch law. This is because many Dutch laws such as the Penal Code (criminal law), the Civil Code (civil law), and colonial ordinances were well established in the country. From a political and legal perspective, drastic changes in the law are rarely wise initiatives, since it would create chaos and instability in the "young" Indonesia. The change in the status of Burgelijk Wetboek (BW) from a statute to a legal book is indicative of the efforts to create a national law. These efforts seem to have been sparked by nationalist movements committed to the passing out of a Dutch law that does not meet the contours of the Indonesian sociopolitical milieu.

For its part, the government tried to unify the diverse Islamic courts and their jurisdictional authority.52 The idea of codification of law which is the essence of Roman law has not been discarded in the efforts to secure legal certainly. The use of various figh books in rendering decisions was limited to just thirteen books on the basis of the Religious Judicial Beaureu's letter no. B/1/735, dated 18 February 1958. The latest efforts to codify Islamic law culminated in the enactment of Kompilasi Hukum Islam di Indonesia (Codification of Islamic Law in Indonesia) based on Presidential Instruction no.1/1991.

The status of religious courts in Indonesia underwent a positive change after independence. The drafting of Government Regulation no. 14/1970 on the authority of attorneys and the enactment of the law of the Religious Judiciary no. 7/1989 are the most important documents to reinforce the equality of religious court with other courts. The improved status of Islamic law in Indonesia is attributable to the Indonesian government's policy of placing proportional emphasis on Islamic law concerning its socio-political importance in the lines of the majority of Muslims. However, the influence of Roman law in the areas of codification of judicial process and legislation

52 See M. Yahya Harahap, Kedudukan Kewenangan dan Acara Peradilan Agama (Jakarta: Pustaka Kartini, 1993), 29. 
cannot be ignored. Indonesia's growing involvement in international legal and diplomatic initiatives continues to facilitate this process.

The strong influence of the idea of codification in Indonesia, furthermore, should also be seen as an impact of the former schooling of Indonesian scholars in Leiden and another Dutch school. The graduates of Dutch law schools played an important role in shaping Indonesian law after independence. However, in the latest developments, many scholars have promoted the enactment of a national law that would eventually phase out colonial laws and replace them with national legislative law. Some steps have already been taken in this regard.

Meanwhile in Malaysia, the development of Islamic law took a different path from that in Indonesia. The difference stems from the situation in the respective areas before age. As mentioned in the introduction, the Malay Peninsula had known codification before the coming of colonialism, while Indonesia experienced it only afterward.

As well, Malaysia and Indonesia both encompass within their borders a multitude of states; some are Sultanates, such as Kelantan, Negeri Sembilan and Johor, while others are not. In Sultanates, the development of Islam is less turbulent than in those without a sultan. Islamic practices received the protection of the Sultan. In the other states, changes and the development in Islamic law were saturated with the influences of English law.

In the post-independence era, the Islamic court in the Sultanates has retained their independence, in the sense that they have preserved their institutions with the Sultan as the chief Kadi. Meanwhile, the other states, such as Penang and Serawak, have subordinated Islamic cases to the authority of civil courts. Although the intensity of British influence is different from one state to others, the influence of common law in every state can be generally considered as strong so far, especially in the early years immediately after independence in 1957.53

The code of civil law 1956 states, moreover, that if there is no written law in Malaysia, the civil court should defer to common law or other suitable laws. This may be explained by the fact that the transfer

53 See Panitia Penyusun Biografi, Prof. KH. Ibrahim Hosen dan Pembaharuan Hukum Islam di Indonesia, 102. 
of authority from the British to the Malaysian hands occurred peacefully following an evolutionary rather than revolutionary process.

However, the diversity of Islamic legal systems and procedures found among states in Malaysia, have paved the road to legal conflict among the states of modern Malaysia. This legal conflict, arising from the plethora of laws, is exacerbated by the nature of common law with its "judge-made" criterion and the resultant variations which arise on the same matters in different states.

Fortunately, the tradition of codification tempers the exigencies described above and renders different decisions on the same mattes unlikely. But in Malaysia, many new codes and laws were enacted, such as the administration of Islamic law in Penang and Malaka (1959), Negeri Sembilan (1960), Kedah (1962), Perlis (1964), and Johor and Sabah in 1978.

Besides, further efforts to develop, change, and codify Islamic law in several states took place in the 1980s. ${ }^{44}$ However, an effort to create uniformity in the family law in the early 1980's faced greater challenges. Some states, such as Kelantan, Kedah, and Malacca rejected the draft made by the committee. ${ }^{55}$

The codification of Islamic law in Malaysia covers not only family law and the administration of Islamic law, but also civil procedural law, criminal procedural law, etc. The drive to do more than just legislation and elevate the position of Shari'a courts and law has been given impetus by the improvement in Islamic legal scholarship. ${ }^{56}$ Within the last decade, a kind of reawakening among Muslim leaders and scholars has to lead to calls for a rehabilitation of the shari' $a$ and demands for equalization with civil courts. ${ }^{57}$

${ }^{54}$ Panitia Penyusun Biografi, 103.

${ }^{55}$ Tan Seri Datuk Ahmad bin Muhamed Ibrahim, "Recent Developments in The Shari'ah Law in Malaysia," in Undang-Undang Keterangan dan Prosedur di Mahkamah, ed. Abdul Munir Yaacob (Kuala Lumpur: IKIM, 1995), 48.

56 Panitia Penyusun Biografi, Prof. KH. Ibrahim Hosen dan Pembaharuan Hukum Islam di Indonesia, 107.

57 Dato' Syed Hamid Albar, "The Syari'ah and The Syari'ah Court in Malaysia," in Undang-Undang Keterangan dan Prosedur di Mahkamah, ed. Abdul Munir Yaacob (Kuala Lumpur: IKIM, 1995), 26, 33-34. 


\section{Conclusion}

This study has demonstrated that the Dutch and British occupation in Indonesia and Malaysia proves Edward Said's assessment of imperialism as a vehicle for cultural hegemony. In terms of the law, the Dutch influence on the development of the legal system in Indonesia cannot be denied. Likewise, British imperialism also impacted the legal systems of Malaysia in a profound sense. Dutch colonialism, which lasted for approximately 350 years in Indonesia, left its mark on the region by introducing Roman law to the Islamic judiciary, as did the 160 years of British colonialism in Malaysia, witnessed in the forced application of common law.

In Malaysia, the influence of the common law system on shari' a and shari'a court is also indisputable. However, the degree of influence fluctuates from some state to the next as a consequence of political, social and legal exigencies. The diversity of Islamic legal sources and the inequality of shari'a courts before the civil court are also the result of various and ambiguous policies promoted by the British. Meanwhile, the pervasive influence and legacy of Dutch rule on the Indonesian legal system is the practice of codification. Islamic law is a manifestation of this practice. Efforts to unify and create uniformity concerning the source of law, have resulted in the enactment of the Law of Marriage no. 1/1974, the law of the Religious Judiciary no. 7/1989, and Kompilasi Hukum Islam di Indonesia (Compilation of Islamic Law in Indonesia) among others. Finally, it must be said that latter-day developments in Indonesian and Malaysian Islamic law particularly must be viewed in the context of globalization, diplomatic relationships among Southeast Asian countries, and the world trends in Islamic thought and development.

\section{Bibliography}

Ahmad Ibrahim. "The Position of Islam in the Constitution of Malaysia." In The Constitution of Malaysia Its Development: 19571977, edited by Muhammad Sufyan (et.al.). Kuala Lumpur: Oxford University Press, 1978.

Anthony J. S. Reid. "Southeast Asia in the Age of Commerce 14501680." In The Lands Below the Winds, 1st ed. New Haven: Yale University Press, 1988. 
B. Schrieke. Indonesian Sociological Studies. Den Haag: W. van Hoven, 1955.

Brian Barrison. Southeast Asia: A Short History. London: Mcmillan \& Co, 1957.

Cammack, Mark. "Islamic Law in Indonesia's New Order." The British Institute of International and Comparative Law 38, no. January (1989).

D. G. E. Hall. A History of Southeast Asia. London: Mcmillan \& Co, 1964.

Danies S. Lev. Islamic Court in Indonesia: A Study in the Political Bases of Legal Institution. London: University of California Press, 1972.

Dato' Syed Hamid Albar. "The Syari'ah and The Syari'ah Court in Malaysia." In Undang-Undang Keterangan Dan Prosedur Di Mahkamah, edited by Abdul Munir Yaacob. Kuala Lumpur: IKIM, 1995.

E. N. Taylor. "Aspects of Customary Inheritance in Negeri Sembilan." In Reading in Malay Adat Laws, edited by M. B. Hooker (et.al). Singapore: University of Singapore Press, n.d.

Edward W. Said., Culture and Imperialism. New York: Vintage Books, 1993.

Foucoult, Michael, Society Must be Defended, New York: Martin Press, 2003.

Feeley, Quinney and Balbus. The Sociology of Law: A Conflict Perspective. Edited by Charles E. Reasons and Robert M. Rich (et.al.). Toronto: Butterworths, 1978.

Gavin W. Jones. Marriage and Divorce in Islamic South-East Asia. Kuala Lumpur: Oxford, Singapore, and New York: Oxford University Press, 1994.

Hansen, Maren. "The Influence of French Law on the Legal Development of Saudi Arabia." Arab Law Quarterly 2, no. 3 August (1987).

Howard M. Federspiel. “The Importance of Islamic Law in TwentiethCentury Indonesia." Ohio, 1995.

I. M. Lapidus. A History of Islamic Societies. Cambridge: Cambridge University Press, 1988.

Iredell Jenkins. Social Order and The Limit of Law. Princeton: Princeton University Press, 1980.

Isma'il bin Mat. "Adat and Islam in Malaysia: A Study in Legal Conflict and Resolution." Temple University, 1985.

Isma'il Sunny. "Kedudukan Hukum Islam Dalam Sistem 
Ketatanegaraan Indonesia." In Dimensi Hukum Islam Dalam Sistem Hukum Nasional, edited by Amrullah Ahmad (et. al.). Jakarta: Gema Insani Press, 1996.

J. N. D. Anderson. "Reflection on Law-Natural, Divene and Positive." In 940'th Ordinary General Meeting of the Victoria Institutes. Westminster, 1956.

Jalaludin, Ahmad. "Budaya Hukum Bias Gender Hakim Pengadilan Agama Dalam Perkara Cerai Talāq." Muwazah 7 (December 2015): 97-210.

Jamillah, Hj. "Judges According To Islamic Law and Indonesian Law In Islamic Court." IOSR Journal of Humanities and Social Science 22, no. 01 (January 2017): 87-93. https://doi.org/10.9790/08372201068793.

Jan Prins. "Adat Law and Muslim Religious Law in Modern Indonesia." The World of Islam 1 (1951).

Latif, Yudi, Negara Paripurna: Historisitas, Rasionalitas dan Aktualitas Pancasila, Jakarta: PT. Gramedia Pustaka Utama, 2012.

Liddle, R. William, Soeharto's Indonesia; Personal Rule and Political Institutions, dalam Pacific Affairs, Vol. 58, No. 1 (Spring, 1985).

Lukito, Ratno, Hukum Sakral dan Hukum Sekuler: Studi tentang Konflik dan Resolusi dalam Hukum di Indonesia, Jakarta: Pustaka Alvabet, 2008.

Mahfudh MD, Moh. Pergulatan Politik dan Hukum di Indonesia, Jogyakarta: Gama Media, 1999.

Mas'udi, Masdar Farid. Agama Keadilan Risalah Zakat (Pajak) Dalam Islam. Jakarta: P3M, 1991.

Matthew B Miles, A Michel Huberman. Qualitative Data Analysis. Jakarta: universitas Indonesia Press, 1994.

Mudjib, Abdul. Principles of Fiqh Science (Al-Qowa'idul Fighiyyah). Jakarta: Kalam Mulia, 2001.

M. Galanter. "The Modernization of Law." In Modernization, edited by M. Weiner (et.al.). New York: Basic Books, 1966.

M. Yahya Harahap. Kedudukan Kewenangan Dan Acara Peradilan Agama. Jakarta: Pustaka Kartini, 1993.

Muhammad Daud Ali. "Kedudukan Hukum Islam Dalam Sistem Hukum Indonesia." In Tradisi Dan Kebangkitan Islam Di Asia Tenggara, edited by Taufik Abdullah and Sharon Siddique (et.al). Jakarta: LP3ES, 1989. 
N. A. Bollach. The Advance of Islam in Indonesia. Islamabad: NIHCR, 1980.

Panitia Penyusun Biografi. Prof. KH. Ibrahim Hosen Dan Pembaharuan Hukum Islam Di Indonesia. Jakarta: Putra Harapan, 1990.

Rais Yatim. Freedom under Executive Power in Malaysia. Kuala Lumpur: Endowment Sdn. Bhd, 1995.

Raymond L. M. Lee. "The Ethnic Implication of Contemporary Religious Movements and Organizations in Malaysia." Contemporary Southeast Asia 8, no. 1 (1986).

Rene David and John E.C. Brierly. Major Legal System in the World Today: An Introduction to the Comparative Study of Law. London: Stevens \& Son, 1978.

Robert L. Kidder. "Western Law in India." In Social System and Legal Process, edited by Harry M. Johnson (et.al). Sun Fransisco, Washington and London: Jossey-Bass Publishers, 1978.

Robert van Niel. "The Course of Indonesian History." In Indonesia, edited by Ruth T. McVey (et.al). New Haven: SAS Yale University, n.d.

Ron Shaham. "Custom, Islamic Law, and Stawary Legislation: Marriage Registration and Minimum Age at Marriage in the Egyptian Shari'a Courts." Islamic Law and Society 2, no. 3 June (1995).

S. Q. Fatimi. Islam Comes to Malaysia. Singapore: Malaysia Sociological Research Institute, 1963.

Sharifah Zal Syed Hassan. "From Saints to Bureaucrats: A Study of the Development of Islam in The State of Kedah Malaysia." Cornell University, 1985.

Syed Naquib Alatas. Preliminary Statement on General Theory of Islamization of the Malay-Indonesian Archipelago. Kuala Lumpur: Dewan Bahasa dan Pustaka, 1969.

Subhan MA. Rahman. "The Dynamic of Malay of Islamic Law The Rise and Practices of Adat Bersendi Syarak, Syarak Bersendi Kitabullah in Jambi." Journal of Indonesian Islam 11, no. 02 December (2017).

Tan Seri Datuk Ahmad bin Muhamed Ibrahim. "Recent Developments in The Shari'ah Law in Malaysia." In Undang-Undang Keterangan Dan Prosedur Di Mahkamah, edited by Abdul Munir Yaacob. Kuala Lumpur: IKIM, 1995. 
W. Friedman. Teori \& Filsafat Hukum. Edited by Muhammad Arifin. Jakarta: Rajawali Press, 1990.

Winstedt. The Malays: A Cultural History. Singapore: Kelly and Walsh, 1947. 